\section{PEMBINAAN KOPERASI, USAHA KECIL DAN MENENGAH INDONESIA}

Buku ini awalnya adalah kumpulan materi ajar bagai mahasiswa dalam perkuliahan program studi administrasi Negara/Publik dan IImu Pemerintahan khususnya pada mata kuliah asas-asas Manajemen dan mata kuliah manajemen perkoperasian dan badan usaha milik desa (BUMDes), serta bidang-bidang yang berkaitan dengan buku ini. Tantangan koperasi Indonesia serta UKM yang lainnya pada masa perdagangan bebas dan Otonomi daerah saat ini yaitu bagaimana kita bisa membangun ekonomi dari masyarakat dengan modal bersama.

Buku ini, diharapkan dapat memberikan pemahaman dan menemukan solusi terhadap permasalahan dan kondisi perkoprasian Indonesia serta UKM, baik di bidang Pemerintahan maupun pelaku-pelaku usaha pada lembaga koperasi dan UKM. Untuk itu, maka penulis berusaha dan memberanikan diri untuk menerbitkan buku ini. Dalam buku Pembinaan Koperasi, Usaha Kecil dan Menengah Indonesia ini, memuat beberapa hal dalam Bab-bab sebagai berikut : Kondisi Usaha Mikro Kecil dan Menengah, Tentang Koperasi, Peranan Koperasi, Problematika Koperasi di Indinesia, Pembinaan Koperasi, Dinas Koperasi Usaha Mikro,Kecil, Menengah dan pengelolaan pasar, dan Sosialisasi Prinsip-prinsip pemahaman Koperasi.

Tanpa adanya peningkatan Koperasi dan UKM yang dapat berperan secara terintegrasi dalam sistem ekonomi Negara, maka pada masa perdagangan bebas dan sangat berperan. Mari bersama kita tingkatkan kekuatan lembaga Koperasi dan UKM untuk meningkatkan ekonomi rakyat di Indonesia.
Drs. Juliman, M.Si

\section{PEMBINAAN KOPERASI, USAHA KECIL DAN MENENGAH INDONESIA}

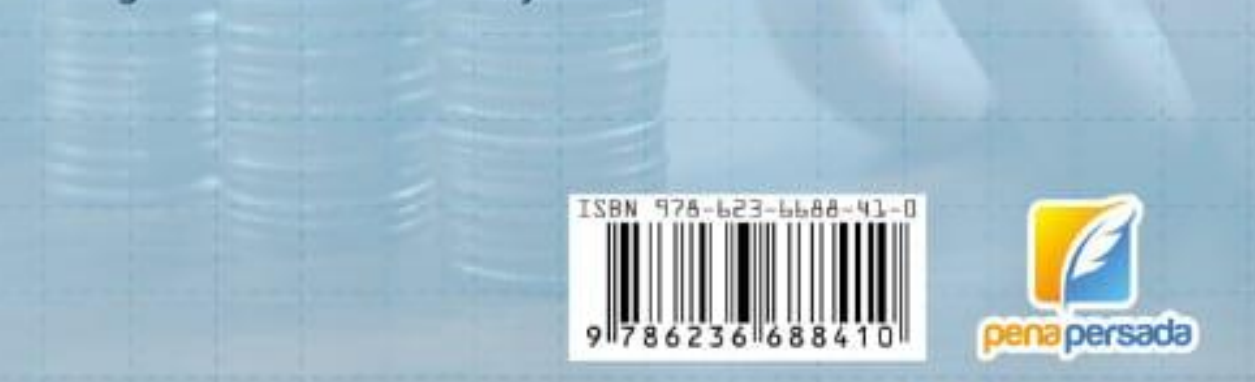




\section{PEMBINAAN KOPERASI, USAHA KECIL DAN MENENGAH INDONESIA}

Drs. Juliman, M.Si

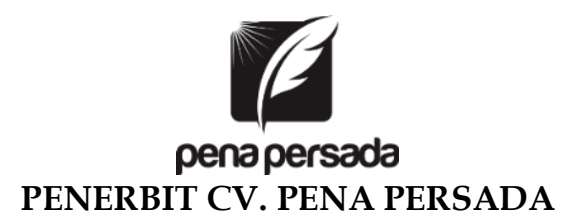




\title{
PEMBINAAN KOPERASI, USAHA KECIL \\ DAN MENENGAH INDONESIA
}

\section{Penulis:}

Drs. Juliman, M.Si

ISBN : 978-623-6688-41-0

\section{Cover Design:}

Retnani Nur Briliant

\author{
Layout : \\ Nisa Falahia
}

\section{Penerbit CV. Pena Persada}

Redaksi :

Jl. Gerilya No. 292 Purwokerto Selatan, Kab. Banyumas

Jawa Tengah

Email : penerbit.penapersada@gmail.com

Website : penapersada.com

Phone : (0281) 7771388

Anggota IKAPI

All right reserved

Cetakan pertama : 2020

Hak Cipta dilindungi oleh undang-undang. Dilarang memperbanyak karya tulis ini dalam bentuk apapun tanpa izin penerbit. 


\section{KATA PENGANTAR}

Sejak diberlakukannnya Otonomi daerah, maka sitem pelaksanaan yang berlaku di Indonesai berubah menjadi yang tadinya sentrlistik kearah dimana sistem pemerintahan di berbagai tngkatan seperti tingkat Provinsi,Kabupaten/Kota dan Desa, wajib mengurus dan mengembanka arah pembngaunan oleh pemerintahan sendiri untuk sepenuhnya kesejahteraa publik yang dilaksanakan bisah dari wilayah lokal sampai dengan gobal. Dengan memanfaatkan fotensi-fotensi yang ada pada kekuatan pemerintahan lokal.

Untuk pelaksanaan kemandirian pembangunan tersebut perlu didukung oleh organisasi yang handal, yang bergandengan dengan pemerintan, Badan Usaha Milik Desa (BumDes), Unitunit keuangan Mikro (UKM) dan usasa-Usaha Masyarakat yang besinergi membangun Pemerintahan di berbagai tingkatan di indonesia. penulis menerbitkan buku ini adalah untuk menyalurkan minat pemanfaatan koperasi yang masih mempuyai kekuatan hokum yang dilindungi UNDANG-UNDANG REPUBLIK INDONESIA. NOMOR 25 TAHUN 1992. TENTANG. P E R K O P E R A S I A N. dan masih menjadi urusan Negara melalu Dinas Perindustrian,perdagangan dan Koperasi(DISPRINDAKKOP). dan buku yang masih sangat sederhana ini muda-mudanan bermanfaat bagi Mahasiswa, pelaku-pelaku usaha mikro, dan dapat menguatkan usaha-usasa yang dibngunan oleh pemerintahan seperti perusahaan Daerah dan BUMDES.untuk ditingkat desa. Selain penguatan-penguatan penggunaan dana yang bersumber dari pemerintah pusat.Untuk menerbitkan buku tentang koperasi ini. Perlu diketahui bahwa permasalahan yang timbul pada saat ini yang diberitakan dari berbagai sumber media menyatakan bahwa jumlah koperasi semakin menurun dan jumlah yang tidak aktif juga semakin menurun. Untuk itu menurut hemat penulis perlu perbaikan-perbaikan pemahan maupaun praktek kerja pada lembaga kopersi indonesia.

Metode mengedukasi pola piker (mindset) masyarakat yang sangat perlu dilaksanakan dari berbagai pihak seperti Perguruan Tinggi, Lembaga swadaya Masyarakat (LSM) lembaga Pemerintah 
dan kelompok-kelompok kepentingan yang lain kepada setiap lapisan masyarakat. Perlu ada penjelasan yang dapat diterima dan dimengerti dari berbagai pihak bahwa sistem pemerintahan kita sudah dari sistem pemerintahan orde baru kepemerintahan reformasi yang menerapkan sitem aspirasi masarakat/publik. Dengan memanfaatkan teknologi abat ke 21 dimana sistem pengelolaan bisa berbasis sistem teknologi informasi. Dimana yang dulu ada istila ketua untung dulu, mudah untuk dikorupsi, hanya keuntungan sepihak saja dan lain-lain bisa di tampik dengan pemenfaatan program-program pengelolaan berbasis tegnologi informasi yang tepat, akurat, mudah dan di jamin aman, dengan asas transparan dan akuntabel dimana semua pihak seperti Badan Pengawas, Pengurus dan anggota bisa mengakses dengan cepat perkembangan Lembaga Koperasi dengan cepat.

Buku ini terbit, tidak terlepas dari bimbingan Allah yang maha kuasa. Untuk itu penulis menghaturkan rasa syukur yang sangat mendalam atas kehadiratnya. Dan penulis juga mengucapkan rasa terimah kasih yang sebesar-besarnya kepada semua pihak yang membantu, sehingga buku ini dapat diselesaikan.

Lubuklinggau, September 2020

Drs. Juliman, M.Si 


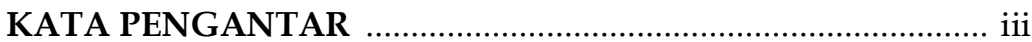

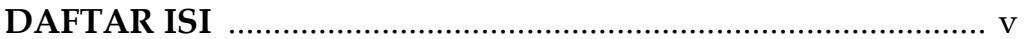

BAB I PENDAHULUAN ……................................................ 1

BAB II KONDISI USAHA MIKRO KECIL DAN

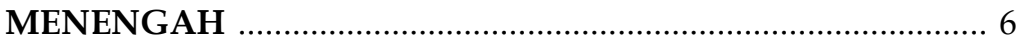

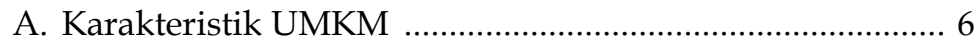

B. Pemberdayaan dan Pengembangan UMKM ........................ 7

C. Terjadinya Ketimpangan dari Segala Aspek Prikehidupan Baik Ekonomi, antar Wilayah, Maupun Sosial dan

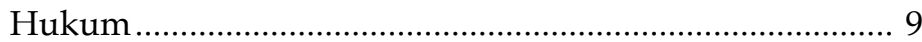

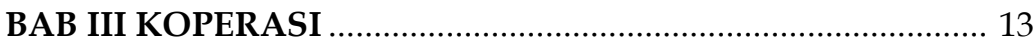

A. Pengertian Koperasi .......................................................... 13

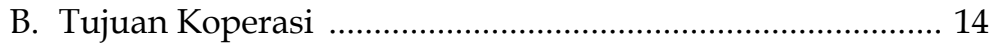

BAB IV PERANAN KOPERASI ………………....................... 16

A. Awalnya Didirikan Koperasi ................................................ 16

B. Peranan Koperasi dalam Masyarakat.................................... 16

C. Peranan Koperasi di Bidang Ekonomi Sosial ..................... 17

BAB V PROBLEMATIKA KOPERASI DI INDONESIA …........ 19

A. Mengoptimalkan Peran Konsultan Keuangan Mitra Bank

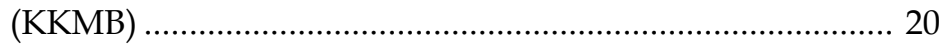

B. Mensosialisasikan Pola Pembiayaan Bagi Hasil atau Pembiayaan Modal Ventura............................................... 22

C. Meningkatkan Peran serta Lembaga Penjaminan Kredit... 22

BAB VI PEMBINAAN KOPERASI ........................................ 25

BAB VII DINAS KOPERASI USAHA MIKRO, KECIL DAN MENENGAH DAN PENGELOLAAN PASAR .......................... 36

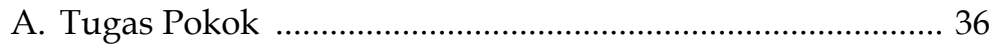

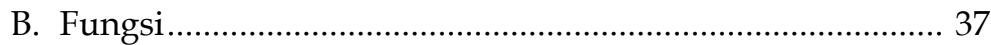

C. Bidang Kelembagaan Koperasi ......................................... 39

D. Bidang Bina Usaha Koperasi, Usaha Mikro, Kecil dan

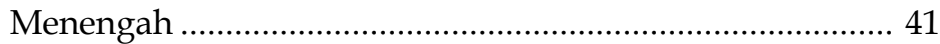

E. Bidang Fasilitasi Pembiayaan .............................................. 43

F. Bidang Pengelolaan Pasar ................................................. 44

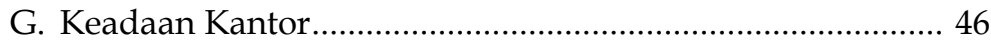


BAB VIII SOSIALISASI PRINSIP - PRINSIP PEMAHAMAN KOPERASI 48

A. Pembinaan, Pengawasan dan Penghargaan Koperasi Berprestasi 49

B. Peningkatan dan Pengembangan Jaringan Kerja Sama Usaha Koperasi ............................................................... 50

C. Perencanaan Pembinaan Koperasi di Kota Lubuklinggau. 52

D. Pelaksanaan Pembinaan Koperasi di Kota Lubuklinggau ......................................................... 54

E. Hambatan/Kendala yang Dihadapi dalam Pembinaan Koperasi di Kota Lubuklinggau 61

BAB IX PENUTUP 63

DAFTAR PUSTAKA 65 


\section{BAB I \\ PENDAHULUAN}

Koperasi diharapkan dapat menjadi soko guru perekonomian Indonesia. Pola pengorganisasian yang melibatkan partisifasi setiap anggota dan pembagian hasil usaha yang cukup adil menjadikan koperasi sebagai harapan pengembangan perekonomian Indonesia. Koperasi dapat menyerap tenaga kerja dan menanggulangi kemiskinan. Hal ini bisa terealisasi jika ada keterlibatan semua pihak dalam arti Koperasi itu sendiri, dinas koperasi, dan kesadaran masyarakat akan pentingnya koperasi.

Berbagai program telah diupayakan untuk meningkatkan kesejahteraan masyarakat baikoleh pemerintah, maupun oleh organisasi non pemerintah. Program-program tersebut bertujuan untuk memperbaiki perekonomian dan meningkatkan kesejahteraan masyarakat, salah satuprogram tersebut adalah koperasi.

Koperasi merupakan salah satu usaha sekaligus gerakan ekonomi rakyat. Pada awalnya, koperasi merupakan kumpulan orang-orang yang memiliki ekonomi tingkat bawah, di mana melalui koperasi mereka sama-sama berkeinginan atau punya tujuan untuk meningkatkan kesejahteraannya. Namun seiring dengan berjalannya waktu koperasi tidak hanya merupakan kumpulan orang-orang yang perekonomiannya lemah akan tetapi juga milik mereka yang tingkat perekonomiannya sudah tinggi. Hal ini karena atas dasar koperasi sesuai dengan sifat dasar bangsa Indonesia yang bersifat gotong royong dan kekeluargaan, yang merupakan pencerminan darinilai-nilai luhur Pancasila dan Undang-Undang Dasar 1945. Hal ini berarti bahwa segala kebijakan yang dibuat oleh pemerintah dalam penyelenggaraan negara tidak boleh bertentangan dengan Pancasila dan UndangUndang Dasar 1945. Dan Pancasila merupakan hukum tertinggi dalam penyelenggaraan negara, baik di bidang ekonomi, politik, sosial dan bidang lainnya. 
Data menunjukkan bahwa jumlah koperasi sampai dengan 31 Desember 2012di Indonesia tercatat sebanyak 194.295 unit dengan jumlah anggota sebanyak 33.869 .439 orang, hal itu menunjukkan bahwa jumlah koperasi di Indonesia begitu banyak yang tujuannya adalah untuk meningkatkan kesejahteraan baik dikalangan bawah maupun di kalangan menengah dengan adanya koperasi. Dan yang lebih mengejutkan lagi ternyata, makin banyak koperasi berstatus tidak aktif. Hingga akhir Desember 2013, yaitu sebanyak 29,74 persen koperasi di Indonesia tidak aktif. Berdasarkan data Kementrian Koperasi dan Usaha Kecil dan Menengah, ada 60.584 koperasi yang tidak aktif dari keseluruhan 203.701 unit. Data Kementrian Koperasi dan Usaha Kecil dan Menengah Desember 2013.JAKARTA, KOMPAS.com(diakses Rabu 08 Maret 2014 | 12:00 WIB)

Secara kuantitas koperasi di indonesia jumlahnya sudah cukup tinggi, namun secara kualitas masih perlu dipertanyakan apakah koperasi tersebut benar-benar berjalan secara sehat dan dapat meningkatkan kesejahteraan anggotanya dan masyarakat pada umumnya. Dan hal senada juga terjadi pada jumlah koperasi di Provinsi Sumatera Selatan yaitu sebanyak 5.122 unit koperasi, jumlah koperasi yang aktif 4.609 dan jumlah kopersai yang tidak aktif adalah 513 unit koperasi,dengan jumlah anggota 798.588, (Dinas koperasi Kota Lubuklinggau sampai dengan desember 2012).

Data diatas menunjukkan bahwa jumlah yang tidak aktif masih mencapai $11 \%$ dari jumlah koperasi yang ada di Provensi Sumatera Selatan, hal itu baru dilihat dari jumlah koperasi dan belum kita tinjau di internal masing-masing koperasi apakah sudah sehat atau masih banyak yang statusnya aktif tapi secara operasional tidak sehat dan belum menyentuh pada inti dari tujuan koperasi yaitu mensejahterakan anggotanya serta mensejahterakan masyarakat pada umumnya.

Koperasi di Kota Lubuklinggau yang ada berjumlah 184 unit dengan koperasi aktif 108dan koperasi non aktif 92 unit koperasi, dengan jumlah anggota sebanyak 8.929 orang (Dinas Koperasi kota Lubuklinggau). Dari data tersebut menunjukkan bahwa di 
Kota Lubuklinggau koperasi yang tidak aktif mencapai 99,36\% dari jumlah koperasi yang ada di kota Lubuklingga dinyatakan tidak aktif, yang dapat dilihat pada tabel sebagai berikut:

Tabel 1.1 : Jumlah Koperasi Yang Aktif dan Tidak Aktif Di Kota Lubuklinggau

\begin{tabular}{|l|l|c|c|}
\hline No & \multicolumn{1}{|c|}{ Jenis Koperasi } & Jumlah Aktif & Jumlah tidak aktif \\
\hline 1 & KPRI & 11 Unit & 6 Unit \\
2 & KOPWAN & 3 Unit & 5 Unit \\
3 & KSU & 52 Unit & 59 Unit \\
4 & KSP & 16 Unit & 5 Unit \\
5 & KOPKAR & 12 Unit & 5 Unit \\
6 & KJKS(KOPONTREN) & 5 Unit & 1 Unit \\
7 & UJKS & 2 Unit & 2 Unit \\
8 & KUD & 1 Unit & 5 Unit \\
9 & KOPINKRA & 1 Unit & 0 Unit \\
10 & KPPDK & 1 Unit & 1 Unit \\
11 & KOPTAN & 2 Unit & 1 Unit \\
12 & KOPPAS & 1 Unit & 0 Unit \\
13 & KOPTUN & 0 Unit & 1 Unit \\
14 & KOP.PENSIUN & 1 Unit & 0 Unit \\
\hline & Jumlah & 108 Unit & 91 Unit \\
\hline
\end{tabular}

Sumber: Kantor Dinas Koperasi, Usaha Mikro, Kecil, Menengah dan Pengelolaan Pasar Kota Lubuklinggau

Tabel di atas menunukkan bahwa koperasi di Kota Lubuklinggau masih memerlukan penanganan serius oleh dinas koperasi Kota Lubuklinggau untuk mengetahui akar permasalahan mengapa banyak koperasi diKota Lubuklinggau memiliki status non aktif. Dengan demikian asumsi dari penulis adalah faktor pembinaan koperasi sangat dipentingkan.

Usaha mikro, kecil dan menengah (UMKM) merupakan pelaku bisnis yang bergerak pada berbagai bidang usaha, yang menyentuh kepentingan masyarakat. Berdasarkan data BPS (2003), populasi usaha kecil dan menengah (UKM) jumlahnya mencapai 42,5 juta unit atau 99,9 persen dari keseluruhan pelaku bisnis di tanah air. UKM memberikan kontribusi yang signifikan terhadap penyerapan tenaga kerja, yaitu sebesar 99,6 persen. Semenrtara itu, kontribusi UKM terhadap Produk Domestik Bruto (PDB) sebesar 56,7 persen. 
Dalam proses pemulihan ekonomi Indonesia, sektor UMKM memiliki peranan yang sangat stategis dan penting yang dapat ditinjau dari berbagai aspek. Pertama, jumlah industrinya yang besar dan terdapat dalam setiap sektor ekonomi. Berdasarkan data Badan Pusat Statistik (BPS) 2002, jumlah UMKM tercatat 41,36 juta unit atau 99,9\% dari total unit usaha. Kedua, potensinya yang besar dalam penyerapan tenaga kerja. Setiap unit investasi pada sektor UMKM dapat menciptakan lebih banyak kesempatan kerja bila dibandingkan dengan investasi yang sama pada usaha besar. Sektor UMKM menyerap 76,55 juta tenaga kerja atau 99,5\% dari total angkatan kerja yang bekerja. Ketiga, kontribusi UMKM dalam pembentukan PDB cukup signifikan yakni sebesar 55,3\% dari total PDB.

Salah satu upaya peningkatan dan pengembangan UMKM dalam perekonomian nasional dilakukan dengan mendorong pemberian kredit modal usaha kepada UMKM. Dari sudut perbankan, pemberian kredit kepada UMKM menguntungkan bagi bank yang bersangkutan. Pertama, tingkat kemacetannya relatif kecil. Hal ini terutama disebabkan oleh tingkat kepatuhan nasabah usaha kecil yang lebih tinggi dibandingkan nasabah usaha besar. Kedua, pemberian kredit kepada UMKM mendorong penyebaran risiko, karena penyaluran kredit kepada usaha kecil dengan nilai nominal kredit yang kecil memungkinkan bank untuk memperbanyak jumlah nasabahnya, sehingga pemberian kredit tidak terkonsentrasi pada satu kelompok atau sektor usaha tertentu. Ketiga, kredit UMKM dengan jumlah nasabah yang relatif lebih banyak akan dapat mendiversifikasi portofolio kredit dan menyebarkan risiko penyaluran kredit. Keempat, suku bunga kredit pada tingkat bunga pasar bagi usaha kecil bukan merupakan masalah utama, sehingga memungkinkan lembaga pemberi kredit memperoleh pendapatan bunga yang memadai. Pengalaman selama ini menunjukkan bahwa ketersediaan dana pada saat yang tepat, dalam jumlah yang tepat, sasaran yang tepat dan dengan prosedur yang sederhana lebih penting dari pada bunga murah maupun subsidi. 
Namun dari beberapa hal yang melatar belakangi seperti tersebut di atas, masih belum cukup menjadi landasan keyakinan bahwa pelaku UMKM akan mendapatkan kemudahan dalam hal pengajuan fasilitas kredit modal usaha ke lembaga-lembaga pemberi kredit baik perbankan maupun non perbankan. Hingga saat ini masih banyak pelaku UMKM yang mengalami permasalahan dalam hal pengajuan kredit usaha. 


\section{BAB II \\ KONDISI USAHA MIKRO KECIL DAN MENENGAH}

\section{A. Karakteristik UMKM}

Menurut Sri Winarni (2006) Pada umumnya, usaha kecil mempunyai ciri antara lain sebagai berikut (1) Biasanya berbentuk usaha perorangan dan belum berbadan hukum perusahaan, (2) Aspek legalitas usaha lemah, (3) Struktur organisasi bersifat sederhana dengan pembagian kerja yang tidak baku, (4) Kebanyakan tidak mempunyai laporan keuangan dan tidak melakukan pemisahan antara kekayaan pribadi dengan kekayaan perusahaan, (5) Kualitas manajemen rendah dan jarang yang memiliki rencana usaha, (6) Sumber utama modal usaha adalah modal pribadi, (7) Sumber Daya Manusia (SDM) terbatas, (7) Pemilik memiliki ikatan batin yang kuat dengan perusahaan, sehingga seluruh kewajiban perusahaan juga menjadi kewajiban pemilik.

Badan Pusat Statistik (2003) di dalam Sri Winarni (2006) mengidentifikasikan permasalahan umum yang dihadapi oleh UMKM adalah (1) Kurang permodalan, (2) Kesulitan dalam pemasaran, (3) Persaingan usaha ketat, (4) Kesulitan bahan baku, (5) Kurang teknis produksi dan keahlian, (6) Keterampilan manajerial kurang, (7) Kurang pengetahuan manajemen keuangan, dan (8) Iklim usaha yang kurang kondusif (perijinan, aturan/perundangan)

Hasil penelitian kerjasama Kementerian Negara KUKM dengan BPS (2003) di dalam Sri Winarni (2006) menginformasikan bahwa UKM yang mengalami kesulitan usaha 72,47 $\%$, sisanya 27,53 \% tidak ada masalah. Dari 72,47 \% yang mengalami kesulitan usaha tersebut, diidentifikasi kesulitan yang muncul adalah (1) Permodalan 51,09 \%, (2) Pemasaran 34,72 \%, (3) Bahan baku 8,59 \%, (4) Ketenagakerjaan 1,09 \%, (5) Distribusi transportasi 0,22\% dan (6) Lainnya 3,93\%. 
Persentase kesulitan yang dominan dihadapi UMKM terutama meliputi kesulitan permodalan (51.09\%). Lebih lanjut disebutkan bahwa dalam mengatasi kesulitan permodalannya diketahui sebanyak 17,50\% UKM menambah modalnya dengan meminjam ke bank, sisanya 82,50 \% tidak melakukan pinjaman ke bank tetapi ke lembaga Non bank seperti Koperasi Simpan Pinjam (KSP), perorangan, keluarga, modal ventura, lainnya.

Sedangkan permasalahan yang dihadapi UMKM dalam mendapatkan kredit modal usaha antara lain adalah (1) Prosedur pengajuan yang sulit 30,30\%, (2) Tidak berminat 25,34\%, (3) Pelaku UMKM Tidak punya agunan 19,28\%, (4) UMKM yang tidak tahu prosedur $14,33 \%$, (5) Suku bunga tinggi 8,82\%, (6) Proposal ditolak (1,93\%).

Menurut Sri Winarti (2004) dengan mempertimbangkan peran penting UMKM dalam berbagai aspek perekonomian dan dalam upaya percepatan pemulihan kegiatan ekonomi, Bank Indonesia memberikan dukungan dalam pengembangan UMKM. Dukungan Bank Indonesia ini termasuk juga dalam rangka mendorong pulihnya fungsi intermediasi perbankan dan menciptakan kondisi perbankan yang sehat.

\section{B. Pemberdayaan dan Pengembangan UMKM}

Dalam rangka mendukung pemberdayaan dan pengembangan UMKM terutama dalam mendorong penyaluran kredit kepada UMKM, upaya Bank Indonesia antara lain melalui penerapan kebijakan kredit, pemberian bantuan teknis kepada UMKM melalui Konsultan Keuangan Mitra Bank, penelitian mengenai pola pembiayaan kepada UMKM, penyediaan sistem informasi pembiayaan usaha kecil dan pemberian bantuan teknis.

Dalam Tatanan kehidupan ekonomi, koperasi, usaha kecil dan menengah mempunyai peranan penting dalam upaya mengentaskan kemiskinan. Koperasi dan UKM akan memberikan kesempatan berusaha dan kesempatan kerja sebagai perwujudan dari program pemberdayaan ekonomi masyarakat. 
Sasaran pemberdayaan ekonomi masyarakat dapat dilihat dari sisi sebagai berikut: Pertama, menciptakan suasana atau iklim yang me mungkinkan potensi masyarakat berkembang (enabling). Kedua, memperkuat potensi atau sumberdaya yang dimiliki oleh masyarakat (empowering). Ketiga, proses pemberdayaan harus melindungi dan mencegah (protecting) yang lemah bertambah lemah disebabkan kekurang berdayaan dalam menghadapi yang kuat.

Dalam perspektif pemberdayaan, keberadaan usaha kecil menengah dengan segala karekteristiknya dituntut untuk menangkap peluang dalam situasi ekonomi yang sangat sulit, yaitu fleksibelitas yang tinggi, dan dengan dukungan manajemen yang memadai dalam menghasilkan produk dan jasa.

Secara umum dapat dikemukakan beberapa karakteristik UMKM, antara lain: (a) Proses produksi dan hasil produksi menggunakan teknologi madya dan sederhana, (b) Menyerap tenaga kerja (padat karya) dan tidak mensyaratkan keahlian khusus, (c) Cenderung tumbuh berkelompok mem bentuk sentra menurut jenisnya, (d) Tumbuh dan berakar dari bakat ke trampilan yang bersifat turun temurun.

Mengacu pada karakteristik yang dimiliki, usaha kecil dan menengah (UMKM) menggambarkan adanya beberapa keterbatasan berupa lemahnya kemampuan mengakses sumber-sumber kemajuan usaha. Kendala berupa rendahnya kemampuan dan akses yang ada pada UMKM tersebut, antara lain: (a) Rendahnya kemampuan akses pada sumber-sumber informasi. (b) Rendahnya kemampuan untuk meningkatkan akses dan peluang pasar. (3) Rendahnya kemampuan dan akses terhadap sumber-sumber permodalan termasuk perbankan. (4) Rendahnya kemampuan dalam pe nguasaan dan pemanfaatan teknologi. (5) Rendahnya kemampuan dalam mengembangkan organisasi dan manajemen. (6) Lemah nya pemben-tukan jaringan usaha atau kemitraan antara sesama usaha kecil dan besar. 
Berdasarkan permasalahan koperasi dan UMKM, diperlukan strategi pemberdayaan usaha dalam rangka memunculkan usaha masyarakat yang produktif dan prospektif.

Untuk itu membedah permasalahan di atas, perlu dirumuskan masalah-masalah yang menjadi fokus tulisan ini, yaitu: Bagaimana kondisi koperasi dan UMKM saat ini, dan bagaimana bentuk peran dari koperasi dan UMKM yang dapat mengentaskan kemiskinan dan mengurangi pengangguran; Bagaimana peranan lembaga keuangan syariah yang ada saat ini dalam memberdayakan koperasi dan UKM; Apa saja strategi yang dapat diterapkan agar terjadi pemberdayaan Koperasi dan UMKM yang mandiri dan tangguh; Upaya-upaya apa yang perlu dilakukan agar pemberdayaan koperasi dan usaha mikro, kecil, dan menengah (UMKM) dapat mengambil peran yang berarti dalam menanggulangi kemiskinan dan mengurangi pengangguran.

Dari beberapa pertanyaan kunci ini penulis mencoba melakukan analisis lebih jauh guna memberi solusi yang mungkin dapat dilakukan. Membicarakan persoalan koperasi dan UMKM kita tidak terlepas dari pem- bahasan sistem ekonomi, karena koperasi dan UMKM merupakan salah satu pelaku ril dalam perekonomian, semenatara itu kita memahami bahwa saat ini bangsa Indonesia menerapkan sistem ekonomi campuran, ada model kapitalisme atau mekanisme pasar yang menentukan semua aspek perekonomian yaitu apa yang diproduksi, kepada siapa dan bagaimana distribusinya, disisi lain ada model sosialisme yang mana dicirikan masih ada nya beberapa kebijakan ekonomi yang masih ditangan negara, semenatara itu sistem syariah masih sementara mencari bentuk

\section{Terjadinya Ketimpangan dari Segala Aspek Prikehidupan}

\section{Baik Ekonomi, antar Wilayah, Maupun Sosial dan Hukum}

Kondisi bangsa Indonesia saat ini masih jauh dari harapan khususnya masih terjadinya ketimpangan dari segala aspek prikehidupan baik ekonomi, antar wilayah, maupun social dan hukum. Untuk itu dapat disimpulkan bahwa system ekonomi yang dianut bangsa Indonsia saat ini tidak mampu 
menyelesaikan masalah, terbukti orang miskin tambah miskin, lapangan pekerjaan tidak tercipta secara memadai sehingga pengangguran makin bertambah, sementara yang kaya makin kaya.

Jalan keluar dari semua masalah adalah perlunya penerapan system ekonomi islam yang dianggap lebih sesuai dan diyakini mampu mewujudkan pemerataan dan keadilan yang berkelanutan sehinggga tercipta kesejahteraan masyarakat Indonesia yang berdasarkan ajaran islam yang dicitakan yaitu Masyarakat Madani.

Sistem ekonomi Islam diyakini mampu membawa masyarakat Islam Indonesia untuk dapat sejajar dengan bangsa lain dalam membangun perekonomian, mengapa demikian karena Indonesia merupakan negara yang mempunyai pemeluk Islam terbesar di dunia. Untuk itu diperlukan upaya mengkaji dan mengembangankan ekonomi islam lewat seminar, penelitian terapan dan penerapan atau praktek di dunia usaha prinsip-prinsip ekonomi islam agar dapat terwujud masyarakat yang sejahtera, adil dan makmur berdasarkan syariat Islam.

Saat ini peranan koperasi dan Usaha mikro kecil dan menengah (UMKM) sangat diharapkan guna memulihkan perekonomian agar bisa segera pulih dari krisis, mengingat koperasi dan UMKM sangat besar peranannya dalam menyerap tenaga kerja dan meningkatkan produksi dan jasa di masyarakat, namun salah satu tantangan sekaligus peluang adalah sanggupkah koperasi dan UMKM menerapkan sistim syariah sebagai dasar dari semua aspek usaha yang pada akhirnya memberi peluang bagi koperasi dan UMKM bekerja berdasar syariah Islam, secara khusus memanfaatkan keberadaan LKS.

Keberadaan UMKM perlu memaksimalkan potensi yang dimiliki, namun saat ini masih banyak penerapan aturan yang tidak kondusif bagi pengembangan UMKM misalnya terlalu banyaknya pungutan dan biaya-biaya yang diterapkan sehingga mengakibatkan biaya tinggi, belum lagi pengurusan ijin 
yang selain menghabiskan waktu juga sangat mahal, yang mana bagi UMKM yang baru memulai usaha merupakan beban yang sangat berat mengingat pemasukan belum ada sudah harus mengeluarkan biaya perijinan yang tidak sedikit. Fenomena ini merupakan suatu kontaproduktif sebab harusnya pihak pemerintah memberi kemudahan lebih dahulu baru meminta hak, atau dengan kata lain bagaimana memperbanyak obyek yang akan dipungut supaya lebih banyak, jangan seperti saat ini menambah pungutan yang sudah ada. Sesuai data tahun 2003 jumlah tenaga kerja yang ditampung oleh usaha mikro dan kecil 7,4 juta orang, usaha menengah 1,2 juta orang, usaha besar 55.760 orang, sementara itu kepedulian pemerintah daerah terhadap UMKM masih relatif rendah hal terlihat dari alokasi anggaran untuk pengembangan UMKM baru 0,85\% secara rata-rata dari Anggaran Pendapatan dan belanja daerah. Jika kita melihat data ini maka kita dapat mengatakan bahwa solusi terbaik untuk mengurangi pengangguran adalah pemberdayaan UMKM melalui LKS.

Untuk itu apa yang diperlu dilakukan, bagaimana melakukannya, dan yang mana harus diprioritaskan dalam rangka pengembangan koperasi dan UMKM yangberwawasan mandiri dan tangguh melaui LKS. Yang pertama sekali harus dilakukan adalah meyakini bahwa koperasi dan UMKM merupakan pelaku ekonomi yang memiliki peran yang besar dalam men sejahterakan masyarakat melalui aktivitas sosial dan ekonomi yang dilaku kan, Sebagai contoh konkrit negara maju yang berhasil dengan UMKM misalnya Amerika Serikat, Canada, Perancis, Jerman, (Eropah Umumnya) Jepang, Korea Selatan, dan Singapura. Salah satu hal yang diperlukan adalah kebijakan-kebijakan penyesuaian dari kebijakan sentralistis ke kebijakan yang berbasis daerah setempat, dimana UMKM dan LKS sebagai salah satu pelaku ekonomi yang bertujuan mensejahterahkan masyarakat keberadaannya betul-betul bermanfaat bagi masyarakat setempat atau daerah sehingga daerah dapat menikmati hasil dari keberadaan UMKM tersebut. 
Selain itu guna mencermati perkembangan keadaan maka koperasi dan usaha mikro kecil menengah harus menyesuaikan diri dengan perkembangan keadaan khususnya penerapan model syariah dalam perekonomian salah satunya adalah pengembangan LKS. Yang akan memiliki tantangan dan peluang yang jika tidak dipersiapkan dengan baik bisa jadi akan menghambat pengembangan koperasi dan UMKM. 


\section{BAB III \\ KOPERASI}

\section{A. Pengertian Koperasi}

Koperasi sebagai bentuk badan usaha yang bergerak di bidang prekonomian mempunyai tatanan manajemen yang agak berbeda dengan badan usaha lainnya,hal ini sesuai dengan yang dikemukakan oleh Iqbal (2010 : 114) mengapa prinsip-prinsip koperasi sangat diperlukan ? karena koperasi mempunyai karakter tersendiri dan berbeda dengan badan usaha lain yang semata-mata mengejar keuntungan karena falsafahnya menurut Widiyati (2010:35) adalah dari, oleh dan untuk anggota.Oleh karena itu pengertian koperasi menurut Subandi (2010:19) berasal dari bahasa inggris (co-operation) yang berarti usaha bersama. Dengan kata lain berarti usaha dilakukan secara bersama-sama yang dapat disebut sebagai koperasi. Menurut Muhammad Hatta (dalam Subandi 2010 : 18) Koperasi didirikan sebagai persekutuan kaum lemah untuk membelah keperluan hidupnya. Mencapai keperluan hidupnya dengan ongkos yang semurah-murahnya, itulah yang dituju. Pada koperasi didahulukan keperluan bersama, bukan keuntungan.

Sedangkan menurut Abrahamson (dalam Jochen Ropke 2012:13) mendefinisikan koperasi yang lebih disukai yaitu "Badan usaha koperasi dimiliki oleh anggota, yang merupakan pemakai jasa (users), fakta ini membedakan koperasi dari badan usaha (perusahaan) bentuk lain yang dimilikinya, pada dasarnya adalah para penanam modalnya (investor)". Dari definisi itu ia menarik kesimpulan penting yaitu fakta bahwa orang-orang membentuk koperasi ialah untuk memenuhi kebutuhannya akan pelayanan, yang sebagian besar dinyatakan dalam tujuan-tujuannya, bagaimana koperasi itu diawasi, dibiayai, dan diopersikan serta bagaimana sisa hasil usaha (SHU) didistribusikan. Tingkat keberhasilan kopersai dalam 